\title{
Shrimp export from Benin vs food safety in Europe: reconcilable interests?
}

Citation for published version (APA):

Kindji Gaspard, K., \& Faure, M. G. (2014). Shrimp export from Benin vs food safety in Europe: reconcilable interests? European Journal of Risk Regulation, 5(2), 187-200. https://doi.org/10.1017/S1867299X00003597

Document status and date:

Published: 01/01/2014

DOI:

10.1017/S1867299X00003597

Document Version:

Publisher's PDF, also known as Version of record

Document license:

Taverne

Please check the document version of this publication:

- A submitted manuscript is the version of the article upon submission and before peer-review. There can be important differences between the submitted version and the official published version of record.

People interested in the research are advised to contact the author for the final version of the publication, or visit the DOI to the publisher's website.

- The final author version and the galley proof are versions of the publication after peer review.

- The final published version features the final layout of the paper including the volume, issue and page numbers.

Link to publication

\footnotetext{
General rights rights.

- You may freely distribute the URL identifying the publication in the public portal. please follow below link for the End User Agreement:

www.umlib.nl/taverne-license

Take down policy

If you believe that this document breaches copyright please contact us at:

repository@maastrichtuniversity.nl

providing details and we will investigate your claim.
}

Copyright and moral rights for the publications made accessible in the public portal are retained by the authors and/or other copyright owners and it is a condition of accessing publications that users recognise and abide by the legal requirements associated with these

- Users may download and print one copy of any publication from the public portal for the purpose of private study or research.

- You may not further distribute the material or use it for any profit-making activity or commercial gain

If the publication is distributed under the terms of Article $25 \mathrm{fa}$ of the Dutch Copyright Act, indicated by the "Taverne" license above, 


\title{
Shrimp Export from Benin vs Food Safety in Europe: Reconcilable Interests?
}

\author{
Kévine Kindji and Michael Faure* \\ In order to secure their fishery products market share in the EU, third countries, especially \\ the developing ones, tend to transplant EU requirements into their domestic legal order. In \\ reality, theses transplanted laws do not correspond to measures to reach a level of protec- \\ tion needed by the country of destination. Based upon the case of Benin, this paper intends \\ to show that when these legal transplants are adversely made, they can in some cases have \\ disastrous effects. It can be argued that an unintended result of EU policy was that it con- \\ tributed to the collapse of the shrimp industry in Benin. The paper moreover argues that de- \\ spite the stringency of the EU requirements, the implementation of its control policy might \\ inadequately protect European consumers of shrimp.
}

\section{Introduction}

The safety of fishery products has drawn much attention in the EU regulatory process because they are considered high risk products that must be handled with a great deal of care to protect consumers from potential harm. This imposition by the EU of very strict sanitary and phytosanitary standards has not gone undisputed. Some have argued that applying these strict EU standards also on imports formally serves tools of consumer protection as reiterated in public debates, but de facto often has the hidden purpose of protectionism ${ }^{1}$. This resulted over the years in an EU policy strengthening legal standards which could result in trade bans and border rejections for third countries. Compliance with EU norms proves

Kévine Kindji is a PhD researcher at the Maastricht European Institute of Transnational Legal Research (METRO) (the Netherlands) with a scholarship from Nuffic. Michael Faure is professor of comparative and international environmental law at Maastricht University and professor of comparative private law and economics at Erasmus School of Law (Rotterdam), both in The Netherlands.

1 This has been the case not only for fishery products, but the suspicions refer more generally to most food of animal origin. See for example Alasdair R. Young and Peter Holmes, Protection or Protectionism? EU Food Safety and the WTO, in What's the Beef? The Contested Governance of European Food Safety, Christopher Ansell and David Vogel eds, (2006) pp 281-306; Kathryn M. Pace, EU Import Notifications as a Protectionist Move: an Examination of the Relation between Tariff and Non-Tariff Barriers in Seafood Trade, MSc thesis (2011), Tsunehiro Otsuki, John S. Wilson and Mirvat Sewadeh, A race to the top? A Case Study of Food Safety Standards and African Exports, World bank.

2 See for example Dianna DaSilva-Glasgow and Mark Bynoe, Strategic Response to Evolving Food Safety Standards: A Case especially difficult for developing countries. In reality the levels of protection at both sides may vary substantially because in some developing countries, there is no strong incentive to develop an intricate food safety law to protect the domestic market. In some African countries, economic development may have a higher priority than food safety as a result of which less emphasis is put on promoting strict safety standards. In view of these considerations, two schools of thought have developed in the literature. On the one hand, some authors support the view of "standards as catalysts" for developing countries, having regard to the fact that compliance may serve for upgrading production systems, thereby enhancing quality and contributing to competitiveness ${ }^{2}$. For example, some countries like Bangladesh ${ }^{3}$ and Sri Lan-

Study of Guyana's Fish Export, Estey Center Journal of International Law and Trade Policy (2012), Vol 13 No 2, 201-215; Donna Roberts and Laurian Unnevehr, Resolving trade disputes arising from trends in food safety regulation: the role of the multilateral governance framework, World Trade Review (2005) 469497; Luz B. Diaz Rios and Steven Jaffee., Barrier, Catalyst, or Distraction? Standards, Competitiveness, and Africa's Groundnut Exports to Europe, Agriculture and Rural Development Discussion Paper, World Bank (2008) 1-83.

3 In 1997, the EU banned shrimps from Bangladesh for noncompliances with its requirements. Although the shrimp export sector suffered considerable losses as a result of the ban, subsequent compliance with HACCP principles enabled an increase in exports. As reported by Yunus (2009), "From the second year the accrued benefits far outweighed the annual costs of the compliance and hence, justify the annual costs incurred. In the long run HACCP compliance helped Bangladesh export additional US\$ 35 million annually". See Yunus, M., EU Ban, HACCP Compliance and Shrimp Exports from Bangladesh. The Bangladesh Development Studies Vol. XXXII, No. 3. (2009) pp41-57 
$\mathrm{ka}^{4}$ have successfully managed to improve their compliance to EU food safety requirements, resulting in increased market access. On the other hand, supporting the view of "standards as barriers", other authors argue that export bans or high compliance costs reduce competitiveness and are strong trade impediments ${ }^{5}$. In Kenya, for instance, repeated EU bans have resulted in a decline of $69 \%{ }^{6}$ of fish exports and led to a restricted access to EU market after exports resumption ${ }^{7}$. Besides, while some countries adopted a proactive approach in front of new stringent standards, the response of others has been rather reactive and oriented towards adjustments through significant regulatory changes. ${ }^{8}$ Within a proactive approach, the exporting country undertakes regulatory changes ahead of time according to the future likely evolvement of standards. In contrast, following a reactive approach, a country would undertake regulatory changes only after new standards have appeared, and require compliance. Although both strategies entail regulatory changes, a proactive approach enables greater flexibility and time to choose the best options according to domestic circumstances.

Developing countries in Africa often tend to position themselves as victims of the EU sanitary measures, which compel them to transplant EU law into their legal order. Moreover, because the standards are evolutive, there is a constant threat of being banned by failure to comply. In reality, the EU position is seemingly rather simplistic: it checks whether the third country has a legislation that conforms or is equivalent to the one of the EU. ${ }^{9}$ Whether approval to export to the $\mathrm{EU}$ is given or retained depends also on the ability of the exporting country to implement the legislation through a well functioning and organized control system.

This paper will basically tell the story of the shrimp trade relations between Benin and the EU, and their impact on food safety regulation in Benin. The analysis points out that while Benin was aiming at exporting shrimp to the EU, it ended up importing EU norms to satisfy EU requirements.

The goal of this paper is to present the case of shrimp export from Benin to examine whether the adverse effects observed are imputable to EU food regulations. These adverse effects may not only have consequences for exporters in developing countries, but for EU consumers as well, since the effectiveness in the implementation of the EU policy can, as we will show, also be doubted. Of course from the European perspective the major concern is food safety related to products entering the EU. That concern for food safety is paramount. ${ }^{10}$ Food safety concerns may therefore often tramp with economic development in nations in Africa or elsewhere.

The remainder of this article is structured as follows: the second section presents Benin and the evolvement of shrimp trade patterns with regard to the EU control system (II). The third section shows the main principles of the food safety legal framework at both sides (III). The fourth (IV) section provides some insights in the interactions between these two sets of legislation and the fifth section addresses the effectiveness of the EU approach (V). Section VI concludes.
4 Dey et al. (2005) reported that following better implementation and enforcement of HACCP procedures, Sri Lanka has been able to increase fish exports to the EU by more than $600 \%$ in three years. See Dey, M., M. Rab, K. Jahan, A. Nisapa, A. Kumar, and M. Ahmed. Food Safety Standards and Regulatory Measures: Implications for Selected Fish-Exporting Asian Countries. Aquaculture Economics and Management, 9(1-2), (2005), pp. 217-236.

5 See among others Steven Jaffee, and Spencer Henson, Standards and Agro-Food Exports from Developing Countries: Rebalancing the Debate, World Bank Policy Research Working Paper 3348 (2004) 1-44; Anh Van Thi Nguyen and Norbert L. W. Wilson, Effects of Food Safety Standards on Seafood Exports to US, EU and Japan, Paper presented at the Southern Agricultural Economics Association Annual Meeting, (2009); Anders, Sven and Caswell, Julie A., Standards as Barriers Versus Standards as Catalysts: Assessing the Impact of HACCP Implementation on U.S. Seafood Imports. American Journal of Agricultural Economics, (2009) Vol. 91, No. 2, pp. 310-321

6 Henson, S., Brouder, A.M. \& Mitullah, W., Food safety requirements and food exports from developing countries: the case of fish exports from Kenya to the European Union. American Journal of Agricultural Economics, 82, (2000), pp. 1159-1169.

7 These bans also involved the other countries exporting Nile Perch to the EU. Unlike Uganda and Tanzania, Kenya had more difficulties to adjust to EU standards. Therefore it was downgraded and went from being on list I (which enabled exports to all EU countries) to List II status (which only enabled to export by means of bilateral agreements with specific EU countries)

8 Luz B. Diaz Rios and Steven Jaffee, supra note 2.

9 This fundamental principle is laid down by the article 11 of the regulation 178/2002 that stipulates: "Food and feed imported into the Community for placing on the market within the Community shall comply with the relevant requirements of food law or conditions recognised by the Community to be at least equivalent thereto or, where a specific agreement exists between the Community and the exporting country, with requirements contained therein.

10 See also Stefano Ponte, Bans, Tests, and Alchemy: Food Safety Regulation and the Uganda Fish Export Industry, Agriculture and Human Values (2007), vol. 24, 179-193. 
Overview of Benin's shrimp processing plants

Source: Plan de Relance de la Filière Halieutique/Diagnostic de la Filière Crevette

\begin{tabular}{|l|l|l|l|}
\hline Designation & CRUSTAMER & FSG & SOBEP \\
\hline Legal Form & LLC & LLC & LC \\
\hline Date of Creation & 1997 & 1994 & 1993 \\
\hline Capital (MXOF) & 170 & 100 & 110 \\
\hline Turnover 2002 (MXOF) & 1319 & 1066 & 792 \\
\hline Turnover 2002 (M€) & 2.00 & 1.62 & 1.20 \\
\hline Permanent Employees & 35 & 20 & 20 \\
\hline
\end{tabular}

\section{The evolution of Benin and the EU's fisheries trade}

\section{What is Benin?}

Benin is a small Least Developed Country ${ }^{11}$ situated in West Africa, and characterized by an extrovert economy, dominated by subsistence agriculture. Benin is not exactly a country endowed with enormous fishing potential. It benefits from an opening on the sea which grants the country a sandy facade extending on 120 kilometres from the Nigerian border in the East to the Togolese border in the West and an Exclusive Economic Zone (EEZ) of about 27,750 $\mathrm{km}^{2}$. The water coverage in Benin is insignificant compared to other countries in similar climatic zones $^{12}$. The great majority of halieutic resources are to be found in the southern regions from the lake Ahémé ( 8.500 ha), the lake Nokoué (15.000 ha) and

11 United Nations, The Least Developed Countries Report 2008, Growth, Poverty and the Terms of Development Partnership 2008, (2011) at p 5.

12 Carolina Domínguez-Torres and Vivien Foster, Benin's Infrastructure: A Continental Perspective. World Bank Policy Research Working Paper Series No. 5689, (2011) at p20 available at SSRN: http://ssrn.com/abstract=1871585, visited on 17/08/2011.

13 Bonaventure Houndekon, Conservation et commercialisation des produits de pêche lagunaire, FAO, Proceedings of the symposium on post-harvest fish technology, (1992).

14 FAO/Fishery and aquaculture country profiles, (2008) Vue générale du secteur des pêches national, République du Bénin, $\mathrm{p} 4$. This is due to its contribution to limit rural depopulation, the dropping of traditional activities and the reduction of demographic and water draining problems noticeable in Cotonou, the economic capital.

15 Commission Européenne, Bénin, Profil Environnemental du Bénin, Rapport Final Provisoire, 2006.

16 République du Bénin/Délégation de la Commission Européenne au Bénin, Diagnostic de la filière crevette, 2009.

17 République du Bénin, Plan de Relance de la Filière Halieutique, Projet Appui au Secteur Privé, 2007. to a lesser extent the lagoon of Porto-Novo (3000 ha). Internal waters provide $4 / 5$ of the national production, and crustaceans represent about $15 \%$ of the main species caught in the southern waters ${ }^{13}$. Fishing is considered as an important binding factor for riparian populations ${ }^{14}$ and, economically, it generates employment, taxes and export revenues earning. Yet, fishery products represent only $1 \%$ of the overall GDP. Generally speaking, fishery products correspond to $50 \%$ of animal proteins consumed ${ }^{15}$. National production covers only $31.9 \%$ of needs in animal protein and Benin resorts to import to cover the deficit.

Fishing is carried out artisanally, using rudimentary means, mostly wooden canoes propelled by paddles. Shrimp fishery is a seasonal activity that lasts about eight months annually; it occupies only 21,000 fishermen including 8,000 engaging in the activity on a seasonal basis ${ }^{16}$. Led by three companies (CRUSTAMER, FSG, SOBEP), and exclusively oriented towards the EU, the industrial shrimp sector was engaged in the export of frozen shrimps that were either whole or prepared by a process of topping, heating, or peeling. Data on shrimp exports go back to 1994, because the first export-oriented processing company (SOBEP) was created the previous year. Table 1 provides an overview of the three companies.

Together, these three companies employ around 1200 seasonal employees during the shrimp season ${ }^{17}$. Since January 2010, only CRUSTAMER and FSG have been authorised by the EU to export fishery products to its territory, as well as a company created in 2003 (Société DIAX), which, nevertheless exports very little quantity of shrimps.

The three companies exported an average of $35^{\circ}$ tons from 1994 to 1997. The export which dropped to 250 tons in 1997, increased to 453 tons in 1998, 
and from then on, an upward trend was observed, reaching over 700 tons in 2002 , which was rightly considered the best year of the shrimp export history of Benin. At this stage, an important event led to a radical change of the shrimp export story.

\section{Inspection missions in Benin and their impact on trade relations}

\section{a. First mission: Diagnostic of the system of shrimp production}

After the BSE crisis and the redefinition of the food safety policy it required, the European Commission initiated its Communication "Commission's Green Paper on food law"18 that propelled the creation in 1997 of the Food and Veterinary Office (FVO). This latter became the organ par excellence of the implementation of EU control policies that should lead to the official certification of third countries exporting fishery products to the EU. In the early days, given the number of Member States to inspect, the multiplicity of third countries, and the small number of the workforce of the FVO, controls were sometimes limited to a mere documentary assessment ${ }^{19}$. But increasingly, on-site visits were conducted by agents of the FVO to assess the actual conditions under which stakeholders involved in the production process operate. Later on, priority was given to third countries with past records of health issues ${ }^{20}$ and to those with a large volume of trade with the EU. Inspections can also answer the request for approval addressed to the EU by a third country or in response to disease outbreaks. Generally, inspection results can be used to refuse, withdraw or modify authorizations for exports to the $\mathrm{EU}^{21}$.

Produced as part of the schedule of missions of the FVO, the inspection of 2002 was the first of its kind in the area of fishery products in Benin ${ }^{22}$. It followed the inscription of Benin for the import of fishery products on June 30, 1998 on the part II of the list annexed to the Decision $97 / 296 / \mathrm{EC}^{23}$, after a documentary assessment of the application for approval was sent to the European Commission. The mission was meant for the evaluation of the "equivalence of the legislation of Benin with corresponding Community requirements and performance of national authorities for the control of conditions of production and export of fishery products to the $\mathrm{EU}^{24 "}$. The inspectors of the FVO visited the Competent Authority (CA), the National Health Laboratory, landing facilities, fishing ports and all three shrimp processing establishments. The shortcomings identified related to two major aspects: first, they singled out the conditions of production themselves, including hygiene and lack of knowledge of good production practices. Second, they referred to the absence or obsolescence of legal measures ${ }^{25}$ that should serve as a basis for control operations to ensure that end products are safe to eat. The corollary of this lack of legal basis was the absence or inadequacy of control procedures
18 Commission's green paper on food law, COM(97) 176 final.

19 Documentary assessment refers to a desk analysis of information provided by third countries on their legal and institutional framework as regards the conditions of production and control of the safety of fishery products, and a report on the overall health status in the country. For instance, in 1998, documentary assessments led to the temporary authorizations of 37 countries, while the 35 others were asked to provide more information and guarantees due to the insufficiency of the first guarantees they provided.

20 Referring to the fact that the FVO would focus on third countries where in the past food exports had shown health problems.

21 FVO missions were classified into two categories: the first missions to audit the Competent Authorities (CAs) are called "evaluation missions", while "inspections" are carried out for the followup to the evaluations. When the results of a follow-up inspection reveal that satisfactory measures had been undertaken, the report is closed. Otherwise, the case is referred to the Commission Services to consider the most appropriate course of action to be taken. (See European Commission, Health and Consumer Protection Directorate-General, Food and Veterinary Office, FVO annual report 2001). The FVO checks compliance with EU food safety and quality requirements at both processing plants and CAs. To ensure transparency, results of the inspection missions are made available promptly to enable the checked country to respond to the observations made, and, if necessary, take neces- sary measures in due course. Missions in third countries enable in the early days the adoption of policies to monitor production standards for fishery products, and decide emergency restrictions when essential improvements were needed (See European Commission, Directorate-General XXIV Consumer Policy and Health Protection- Food and Veterinary Office, Food and Veterinary Office Annual Report April 1998- March 1999).

22 The 2002 mission was conducted on the basis of three main EU texts that were then in force, namely Directives 91/493/EEC and 92/48/EEC and Decision 98/140/EC. The current regulatory framework in the EU will be discussed in more detail below III-1.

23 Commission Decision 97/296/EC drawing up the list of third countries from which the import of fishery products is authorized for human consumption, OJ 1997 L 122.

24 Commission Européenne, Rapport concernant une mission en République du Bénin du 7 au 11 Octobre 2002 concernant les conditions de production et d'exportation vers I'Union Européenne des produits de la pêche, DG(SANCO)/8719/2002 MR Final, (2003) at p4.

25 The six texts then presented were still in draft form and contained gaps in the definition of essential parameters such as maximum limits for contaminants in the natural environment, histamine and additives, the list of food contact materials, cleaning and disinfection products allowed. 
with regard to the organization of landing activities, the collection of freshly caught shrimps, the uneven implementation of production principles, and the use of questionable methods by operators such as hyperchlorination. As a result, the inspection team concluded that the CA for fishery products in Benin had no legal basis to set up a monitoring system to ensure and certify the export of products in conformity with EU requirements ${ }^{26}$. Therefore, Benin was found not to be able to guarantee and certify the compliance of products exported to the EU as regards the requirements of Directive 91/493/EEC ${ }^{27}$ concerning the production and placing on the market of fishery products.

These observations of the FVO undoubtedly had a factual basis and the critical comments concerning the system of food safety control in Benin can hence as such be understood.

The shortcomings identified during the mission have led to recommendations to take corrective actions. As a matter of fact, Beninese authorities were invited to provide the FVO with a written undertaking in the form of guarantees, together with a detailed timetable. The remedial measures proposed were to be assessed by the Commission services and, in case of positive assessment, would give rise to a new FVO visit. In reaction, Benin submitted both an action plan and an application for funding to the European Commission within the framework of a project entitled "Improving the health of fishery products in Benin", which resumes some of the corrective measures of the action plan.

Notwithstanding this action plan, the FVO inspectors suggested to the Commission to "consider the

26 Commission Européenne, supra note 24, at $\mathrm{p} 6$

27 Council Directive 91/493/EEC laying down the health conditions for the production and placing on the market of fishery products, OJ 1991 L268.

28 Benin was listed on the list II of the annex to Regulation 2076/2005/EC (Commission Regulation laying down transitional arrangements for the implementation of Regulations (EC) No $853 / 2004$, (EC) No 854/2004 and (EC) No 882/2004 of the European Parliament and of the Council and amending Regulations (EC) No 853/2004 and (EC) No 854/2004, OJ 2005 L338/83), amended by Commission Regulation 1666/2006 of 6 November 2006. This regulation gave approval to Benin to export to the EU through bilateral agreements.

29 This new self-imposed measure was implicitly taken by the government of Benin, which was supposed to give a financial compensation to the companies accordingly.

30 Joseph Ouaké, Officer of the Industry and Commerce Ministry in Benin, in Trading Safely: protecting health, promoting development - Benin, STDF video, 2009. need to take protective measures proportional to the deficiencies identified ". Guarantee measures immediately suggested by the authorities in Benin were considered insufficient by the FVO to overcome the weaknesses identified. As a result, a few months after the visit, in August 2003, Benin decided unilaterally to temporarily suspend all shrimp exports to the EU in order to improve the conditions of production and control of shrimp in the country. This measure was maintained for eighteen months. In February 2005, the voluntary export ban decided in Benin was lifted by the EU, which gave its official approval to receive again fishery products from Benin through regulation 2076/2005/EC ${ }^{28}$. However, before this ban was lifted, processing companies were urged to destroy all stocks still in their possession. 189 tons of shrimps, valued at 700 million CFA francs, more than one million $€$, were destroyed in early $2005^{29}$. Given the consequences of the suspension and the destruction of stocks, companies have not been able to benefit from the end of the suspension. Exports never really revived: two companies resumed their activity, and were later on obliged to stop due to financial constraints. As a result, 175 tons of shrimp were still exported in 2005, but exports fell to 32 tons in 2006 . The following years had not been more successful with respectively 54.6 and 6.2 tons exported in 2007 and 2008. But yet, alerts were raised about Benin's shrimps within the framework of the Rapid Alert System for Food and Feed (RASFF) of the EU. These notifications, three in 2005 and one in 2006, were all about excessive rates of sulphite in frozen whole raw shrimps. This could be explained by the tightening of controls following the recommendation of the FVO's inspectors to test the products from Benin against sulphite residues.

It is important to note that neither the FVO nor the EU Commission ever formally prohibited import of shrimps from Benin. In any case, the results of the FVO were such that the Benin authorities understood that shrimp exports were, after the first FVO inspection, pointless, and individual consignments could still be blocked at the EU border with catastrophic financial consequences for Benin exporters. Beninese authorities then felt it wiser to anticipate potential EU measures against the country. According to them, a EU ban would have been much worse and more difficult to overcome: "To do nothing was risky. The damage of a European ban would have lasted much longer ${ }^{30}$." That is why Benin decided unilaterally to 
suspend shrimp export to the EU and to work jointly with the EU on an improvement of food safety conditions, hoping on a more positive attitude of European authorities. It is in the framework of these "negotiations" 31 that the EU could also require the destruction of existing stocks in Benin in early 2005, even though this measure had no formal legal basis.

\section{b. Second mission: Assessment of the implementation of upgrading measures}

The second mission in 2009 aimed also to assess whether official controls by the CA can ensure that the conditions of production of fishery products in Benin intended for export to the EU are equivalent to the requirements of the Community ${ }^{32}$. Through this goal, this mission gave recognition of the significant improvements in the sector since 2002. Indeed, many changes occurred both in legislative and institutional terms. Beyond the adoption of several texts, the CA was reorganized, training was given to stakeholders, some laboratories are in the process to be accredited, some infrastructures ${ }^{33}$ were built along one lake to assess directly the quality of freshly caught shrimps before they are released for processing. Besides, works were in progress for the creation of a Beninese Food Safety Authority that must play a key role in the implementation of risk analysis.

Overall, the inspection team declared that the Beninese legislation could be considered equivalent to EU requirements although some texts have not yet been published in the Official Journal. However, the fact remains that deficiencies were also detected in the new control system. They are mostly poor sanitation at landing sites while raw materials must necessarily pass by them. In spite of the census done with regard to fishermen, there was no system to prevent unregistered fishermen to also supply collectors with products. Controls were not regularly and sufficiently made in accordance with the schedule and following the rules provided for this purpose in the manual of inspection. In addition, the system put in place did not allow the CA to certify all entries listed in the health certificate. Consequently, the control system was not considered equivalent to the relevant part of EU legislation, in this respect the first chapter of the Annex III of Regulation 854/2004.

Moreover, because the processing plants were closed, the CA found it no longer necessary to carry out the usual controls. Therefore, obvious deficien- cies in the control system of these plants had not been identified by the inspectors of the CA. Nevertheless, due to their approval by the EU, FVO inspectors extended their control to those plants and reported deficiencies in the implementation of HACCP plans, lack of knowledge of the conditions of use of preservatives or additives, and hygienic handling defect. The team noted that procedures did not provide for the suspension of approval for establishments which stopped their activities, violating the article 12 of EU regulation 854/2004. Given all these shortcomings, the implementation of the food legislation with regard to the functioning of factories was still deemed not to be equivalent to the relevant rules of $\mathrm{EU} \mathrm{law}^{34}$.

In conclusion, the FVO inspectors had found that one could not consider that "the organization of the $\mathrm{CA}$ and the implementation of national provisions on which is based the control of fishery products intended for export to the EU were at least equivalent to EU requirements." However, this did not prevent the EU from formally recognizing Benin as a country that can export fishery products to the EU as from January $2010^{35}$. But today the industry is almost at rest: one company closed down, the premises of the second are seized by the tax administration, and the third one is closed for renovation. In reality they are overindebted and all lack the financial capacity to get back into their activities ${ }^{36}$.

\section{Regulatory frameworks}

We will now briefly recall the development of EU food standards, indicating that in the relationship to

31 Whereby de facto the EU dictates under which conditions it would accept shrimp export from Benin again.

32 The mission of 2009 was carried out on the basis of the article 46 of regulation 882/2004 and the Decision 98/140/EC.

33 These are Obligatory Base of Control and Platform of Transfer.

34 Chapter III of Section VIII of Annex III of Regulation (EC) No 853/2004 and Article 5 of Regulation (EC) No 852/2004.

35 Commission Decision 2009/951/EU of 14 December 2009 amending Annexes I and II to Decision 2006/766/EC establishing the lists of third countries and territories from which imports of bivalve molluscs, echinoderms, tunicates, marine gastropods and fishery products are permitted, OJ L328/70 of 15 December 2009.

36 For instance, an own interview revealed that one shrimp company used to benefit from a prefunding from its main customer right at the beginning of the shrimp season. This gave that company an undeniable advantage because it had a good financial flexibility, which also facilitated banking transactions. 
third countries they de facto have an extraterritorial effect (1); next, we will turn to food safety standards in Benin showing that under pressure from the EU, Benin de facto copy-pasted European food law into its own legislation (2).

\section{EU food safety standards}

\section{a. The development of the General Food Law}

The current EU food regulatory regime is a comprehensive and integrated approach to food safety ${ }^{37}$. It was established in 2002 by the regulation EC No $178 / 2002^{38}$, commonly called the General Food Law (GFL). In the EU context, 'food law' refers to the laws, regulations and administrative provisions governing food in general, and food safety in particular, whether at Community or national level. In 2004, a set of regulations was adopted, commonly referred to as the

37 The GFL does not explicitly define food safety, but, on the contrary, it states the conditions of an unsafe food: "Food shall be deemed to be unsafe if it is considered to be injurious to health or unfit for human consumption", taking into account normal conditions of use.

38 Regulation (EC) No 178/2002 laying down the general principles and requirements of food law, establishing the European Food Safety Authority and laying down procedures in matters of food safety; OJ 2002 L31.

39 Food hygiene refers to "the measures and conditions necessary to control hazards and to ensure fitness for human consumption of a foodstuff taking into account its intended use". (Regulation 852/2004, article 2.a).

40 Raymond O'Rourke, European food law, Palladian Law Pub., (1998).

41 Regulation 852/2004 on the hygiene of foodstuffs, OJ 2004 L139. It sets basic rules and principles applicable to food business operators throughout the food chain.

42 Regulation 853/2004 laying down specific hygiene rules for food of animal origin, OJ 2004 L 226. It defines specific hygiene rules to be applied to food of animal origin.

43 Regulation 854/2004 laying down specific rules for the organization of official controls on products of animal origin intended for human consumption, OJ $2004 \mathrm{~L} 226$. It sets the rules to be applied by national authorities for the control and enforcement of food hygiene policies.

44 Regulation 882/2004 on official controls performed to ensure the verification of compliance with feed and food law, animal health and animal welfare rules, OJ 2004 L 191.

45 Risk analysis is a process consisting of three separate but integrated components namely risk assessment, risk management and risk communication. Risk assessment is a process by which scientists evaluate the potential for adverse health or environmental effects from exposure to naturally occurring or synthetic agent (See Risk Assessment: What's it all about?Society of toxicology's newsletter, Communiqué, Special Issue, p. 9 (1998) at p1. According to article 3.12 of the GFL, risk management means the process, distinct from risk assessment, of weighing policy alternatives in consultation with interested parties, considering risk "food hygiene package ${ }^{39 "}$. The current hygiene legislation, which has been qualified as a "patchwork" of different pieces of legislation ${ }^{40}$, comprises the Regulations $852 / 2004^{41}, 853 / 2004^{42}$, and $854 / 2004^{43}$, along with Regulation $882 / 2004^{44}$ on official controls addressed to CA's.

The EU food legislation is based on a farm-to-fork system and the implementation of requirements derived from transparency and proportionality and, wherever applicable, based on the principles of risk analysis ${ }^{45}$ which comprise the precautionary principle $^{46}$. The GFL establishes the primary responsibility of Food Business Operators (FBO's) to ensure that food to be placed on the market meets the requirements of food law, with the understanding that they must implement the principles of HACCP ${ }^{47}$, including the obligations of traceability of own checks thereon. EU Member States and the EU Commission share competence with regard to the enforcement of the food legislation. assessment and other legitimate factors, and, if need be, selecting appropriate prevention and control options. Risk communication is defined by article 3.13 of the GFL as the interactive exchange of information and opinions throughout the risk analysis process as regards hazards and risks, risk-related factors and risk perceptions, among risk assessors, risk managers, consumers, feed and food businesses, the academic community and other interested parties, including the explanation of risk assessment findings and the basis of risk management decisions.

46 As a part of risk management, the precautionary principle enables the adoption of provisional measures in specific circumstances where, following an assessment of available information, the possibility of harmful effects on health is identified but scientific uncertainty persists. Regulation 178/2002, supra note 40, Article 7 . The importance of risk analysis in handling food risks has previously been recognized through the communication from the Commission on the precautionary principle (See Commission of the European Communities, Communication from the Commission on the Precautionary Principle, COM (2000) 1, 2000). This paper has outlined the various components of risk analysis, while emphasizing the need to apply the precautionary principle in cases of scientific uncertainty. The application of the precautionary principle which is mentioned in the Treaty only in relation to the environment, must be extended to risks related to human, animal and plant health, taking into account the costs and benefits of action or lack of action.

47 HACCP is as systematic and science based approach that enables the detection of potential food safety hazards in order to take preventive measures accordingly. The adoption of a HACCP procedure consists in identifying along the process of preparation, processing and distribution the stages essential for food safety. Called Critical Control Points (CCPs), those stages are the basis for the detection of potential hazards in foodstuffs, and represent the way forward to the setting down of the most adequate system for their prevention, elimination or reduction to acceptable levels. Overall, the HACCP consists of seven distinct principles: aConduct of a hazard analysis; b- Identification of CCPs; c- Establishment of critical limits at CCPs; d- Establishment and implementation of effective monitoring procedures at CCPs; e- Establishment of corrective actions; $f$ - Establishment of verification procedures; g- Establishment of documentation and record keeping. 


\section{b. Extraterritoriality}

As regards third countries, "Food and feed imported into the Community for placing on the market within the Community shall comply with the relevant requirements of food law or conditions recognised by the Community to be at least equivalent thereto or, where a specific agreement exists between the Community and the exporting country, with requirements contained therein" ${ }^{\prime 4}$. The EU Commission must delegate experts to perform on-spot inspections to assess the conformity or equivalence of their legislation with Community's requirements. These inspections constitute the basis of numerous decisions concerning imports within the EU. The irregularities detected could lead either to the simple imposition of sanitation procedures, or to the suspension or withdrawal of the establishment's approval. In the case of consignments from third countries, such actions could result in the seizure of consignments followed by the destruction or the re-dispatch of products outside the Community.

For products of animal origin, the most important import standard is the requirement of a formal approval of the third country or a part of it. In that respect a list of authorized countries is drawn up and updated by the Community, according to a wide range of criteria generally comprising the ability of the legislation to comply with general and specific European requirements, the financial and material capacity of CA's to implement, enforce and properly control rules set up by that legislation ${ }^{49}$. Moreover the same prerequisite is compulsory for establishments in third countries which intend to export products of animal origin to the EU. However, in this case, the ability of the CA to provide sufficient guarantees is a precondition which decides whether the establishment could even benefit from the opportunity of a conformity assessment procedure ${ }^{50}$. Such a responsibility underlies the legal power of the CA to stop exports to the EU when an establishment is found failing to comply with essential requirements.

Official controls on the production and placing on the market of fishery products are to include, in particular, regular checks on the hygiene conditions of landing and first sale, inspections at regular intervals of vessels and establishments on land, including fish auctions and wholesale markets and checks on storage and transport conditions ${ }^{51}$. The detection in excess of contaminants and residues, the non-com- pliance with relevant legislation on organoleptic, chemical, physical or microbiological elements, the presence of poisons are all sufficient grounds to declare a fishery product unfit for human consumption.

\section{Benin's food safety standards}

\section{a. The first attempts at regulation}

The 2002 FVO mission and the recommendations contained in the report were the catalyst for a series of reforms at various levels in response to what amounted to a legislative lethargy in Benin in the field of food. An immediate reaction was given in the form of commitments made by Benin through its action plan. The decree $114^{52}$ on the quality assurance ${ }^{53}$ of fishery products has been adopted in April 2003, even before the government decision to suspend shrimp exports, to implement the law 84-009 on control of foodstuffs. The decree 114 defines the regime of the health rules for fishery products, their conditions of processing, preservation, and marketing, as well as the tax system related to these products. This decree paved the way for the adoption of a set of seven other orders in the same year that deal with questions related to establishments, hygiene, good laboratory practices and to limits of certain substances in fishery products.

48 Regulation 178/2002, Article 10.
49 Regulation 854/2004, Article $11(4)$.

50 Due to their particular activity, some establishments do not need a prior authorization to export towards the EU. There are mainly establishments carrying out only primary production, transport operations, storage of products of animal origin, not requiring temperature-controlled storage conditions. Besides, some products of animal origin were not assigned any specific hygiene requirements by the regulation 853/2004 laying down specific hygiene rules for food of animal origin. In the same way, the latter are not required to appear on a list of authorized establishments.

51 Regulation 854/2004, Annex III.

52 Decree No. 114, laying down the quality assurance of fishery products in the Republic of Benin, OJ 2003 No. 20.

53 Quality assurance is defined as all the concerted and systematic measures necessary to obtain reasonable assurance that a product or service meets given requirements of quality. As such, quality assurance constitutes a strategic function that works together with the quality control to achieve its goal. In this regard, quality control should be understood as a technical function that includes all the technical and operational activities implemented to meet the requirements of product quality 


\section{b. Second series of regulation: Copy-pasting EU food law}

In 2009, within the space of two months, five new texts were adopted with regard to food safety in Benin. Rather than merely focusing on fishery products as the previous texts did, these new texts are dedicated to the regulation of foodstuffs in general. Quite surprisingly, they correspond literally with the texts in force within the EU. This implies in particular that they entirely subscribe to all the principles and measures described above with regard to EU food law. As we will indicate below, this led to the occurrence of rather meaningless references to European law that can now be found in Benin food law.

Such an approach has the merit of strengthening Benin's legislation and making it more compliant with the holistic approach in fashion internationally. However, it is clear that as much as the first steps were hard to be applied properly for lack of resources, be it human, material or financial, the new measures would even have a harder time finding a way through the administrative and legal structures in Benin. Obviously, it is quite pointless to adopt a legal framework that would appear to be totally unimplemented and unenforceable. Scholarship acknowledges that regulatory efforts in developing countries should aim at designing regulation which is appropriate to the legal, economic, political, and social situations in which they must function ${ }^{54}$. The literal transposition of EU food law into Benin law seems to continue the old habit of some African countries of importing the laws of the former colonizers. While legal borrowing and legal transplants are certainly not new concepts,

54 Michael Faure, Morag Goodwin and Franziska Weber, Bucking the Kuznets Curve: Designing Effective Environmental Regulation in Developing Countries, Virginia Journal of International Law, Vol. 51 pp. 95-157 (2010), at p. 100.

55 Daniel Berkowitz, Katharina Pistor and Jean-Francois Richard, The transplant effect, The American Journal of Comparative Law, Vol. 51, No. 1 pp. 163-203, at p 167

56 Legality is determined by the ability of a country to give meaning to the transplanted formal legal order and to apply it within the context of its own socioeconomic conditions (See Daniel Berkowitz, Katharina Pistor and Jean-Francois Richard, supra note 55 at $\mathrm{p}$ 167).

57 Daniel Berkowitz, Katharina Pistor and Jean-Francois Richard, supra note 55, at p 189.

58 The government had indeed to incur expenses to support companies to compensate for their losses and had made financial commitments in relation to projects funded by the $\mathrm{EU}$ and by the Belgian Technical Cooperation. For instance, the equipment of laboratories within the framework of the Quality Program (funded for such a transplanted law to be effective, it must be meaningful in the domestic context so as to provide an incentive to citizens to use it, and demand institutions that work to enforce and develop the law ${ }^{55}$. In effect, legality ${ }^{56}$ is a function of the demand for law, and only a high demand can impulse high voluntary compliance, leading a society to invest in legal institutions necessary for upholding the legal order ${ }^{57}$.

In this particular case, there was no such demand for a food safety law, or at least there was no strong demand of regulation for the domestic market itself. All legal provisions adopted in this domain in Benin since 2003 only satisfy the compelling need to meet EU requirements in fear of being excluded from the shrimp export trade. This also explains why, in most cases during the upgrading process, the Benin government was quite slow in making available the funds necessary to implement the law, and in some instances failed to do $\mathrm{so}^{58}$.

\section{c. Other West African countries}

The observation of other cases in the West African Region shows various results. While some countries like Senegal and Ivory Coast tend to have a better reactivity in front of non-compliances detected by the FVO, others like Benin and Togo are slower in undertaking reforms. These two groups of countries share between themselves some common features. With regard to traded volume, Senegal and Ivory Coast exported respectively 43.000 and 25.000 tons of fishery products in $2011^{59}$. Before the ban, Benin, in its best year in 2002, exported only about 700 tons, while neighbouring Togo exported 1.500 tons in $2001^{60}$.

by the EU and implemented by UNIDO) has been stopped at some point because Benin did not keep its promises with respect to the estimates.

59 Ivory Coast also exported about 100.000 tons through directly transshipped in the EU from freezer vessels flying the flag of either a third country or a EU Member. See respectively Commission Européenne, Rapport d'Un Audit Effectué au Sénégal du 22 Janvier au 01 Février 2013 afin d'Evaluer les Systèmes de Contrôle en Place Régissant la Production des Produits de la Pêche Destinés à I'Exportation vers I'Union Européenne, DG(SANCO) 2013 6708 - RM FINAL, 2013; Commission Européenne, Rapport d'Un Audit Effectué en Côte d'Ivoire du 22 Janvier au 01 Février 2013 afin d'Evaluer les Systèmes de Contrôle en Place Régissant la Production des Produits de la Pêche Destinés à I'Exportation vers I'Union Européenne, DG(SANCO) 2013-6706 - RM FINAL, 2013

60 Another 1000 tons were transshipped in the EU. See Commission Européenne, Rapport Final Concernant une Mission Réalisée au Togo du 14 au 18 Octobre 2002 Concernant les Conditions de Production et d'Exportation vers I'Union Européenne des Produits de la Pêche, DG(SANCO)/8698/2002 - MR Final, 2002 
With regard to compliance, the systems in both Senegal and Ivory Coast were found compliant to the one of the EU already in 1997. Although compliance issues were later reported by the FVO, both countries managed to take necessary steps to upgrade to a satisfactory level ${ }^{61}$. In contrast, the deficiencies in Benin and Togo were much harder to overcome. Both countries decided to suspend their shrimp exports to the EU in 2003, and to apply for EU funding to undertake regulatory and institutional reforms. Despite EU assistance, the outcome of the upgrading process is not very positive. While the shrimp export sector in Benin has practically disappeared, Togo is facing an official EU ban for fishery products except live lobsters. These examples point out that many factors can influence an upgrading process. When the stakes are high, the reactivity and the commitment of domestic stakeholders tend also to be higher, resulting in a better outcome. High-quality food safety standards then become catalysts, contributing to building capacity to ensure higher safety of the fishery products for the export supply-chain, which might later result in positive spillovers on the domestic market. But standards will act as barriers for smaller industries, especially when they rely heavily on only one outlet market. Besides, exclusive reliance on external aid to undertake reforms cast some doubts as regards the viability and the sustainability of the improved food safety system. Technical assistance in Benin and Togo have led to better laws, but not to more effective food production and controls systems. One should not lose sight that law is not an end in itself, but is always a means to other ends ${ }^{62}$. In Benin, the aim was to at least formally have the law required by the EU and ironically in a way they succeeded in that. This case is the perfect example that "legal reforms viewed simply as technical assistance programs that can be implemented by having Western experts design good laws, are unlikely to produce the desired outcome, i.e. an effective legal order and economic growth and development ${ }^{63 "}$.

\section{Interdependencies between Benin and EU food laws}

The implementation of food law is not without risks or potential flaws, not even within the EU. The current EU legislation was the outcome of a long process that enabled to capitalize on experiences and mis- takes in order to realize over time the adjustments necessitated by either structural constraints or scientific contingencies. Even if the implementation of the hygiene package did not create major difficulties for FBOs and CAs in the EU, it is still slightly cumbersome for some small establishments. The findings of the relevant FVO missions show that some small businesses were sometimes obliged to use external consultancy, which was in some cases not relevant for the reality of their establishment, resulting in more documentation and records than mandatory. Besides they were not efficient and overly expensive. Some minor problems were raised about the difficulties to satisfy the record-keeping requirement, which is seen as an administrative burden. At the same time, the guides to good practice were appreciated for their valuable inputs for primary producers. ${ }^{64}$ Similarly, the institutional support progressively improved to cope with changes in the legal requirements adopted. The fact remains that while the rules were being strengthened for EU Member Countries and their operators, they were equally hardened for third countries, especially with the advent of the conformity or equivalence requirement. As we just showed, this has placed Benin in the skin of most developing countries that become "regulation takers" 65 for the sake of their commercial interests. In so doing, some of them expect to be able to reach from scratch the same institutional and operational level as the EU. This has proved to be very difficult for Benin, given that already for a decade it continues to struggle to implement the necessary framework. To name just a few problematic issues: laboratories are still not accredited, and the fishermen are only partially identified ${ }^{66}$.

61 However, it should be noted that the FVO reported in 2013 that doubts remain about the reliability of the results of laboratory analysis in Ivory Coast. Likewise, some shortcomings were pointed out in the control system and some recommendations from earlier FVO reports were yet to be applied.

62 Alan Watson, The Evolution of Western Private Law, The John Hopkins University Press, (2001) at p. 198.

63 Daniel Berkowitz, Katharina Pistor and Jean-Francois Richard, supra note 57 , at p. 190.

64 See European Commission/Directorate-General for Health and Consumers, Report from the Commission to the Council and to the European Parliament on the experience gained from the Implementation of the Hygiene Regulations (EC) No 852/2004, (EC) No 853/2004 and (EC) No 854/2004 of the European Parliament and of the Council of 29 April 2004, European Communities 2009.

65 Stefano Ponte, supra note 10.

66 This was an important step to properly ensure the obligation of traceability as required by the food law. 
Yet, despite this validation and institutional changes that ensued after the advent of the GFL and the hygiene package, Benin still felt obliged to change its standards once again, this time by simply copying the texts in force within the EU. This is all the more disturbing since the texts are sometimes misunderstood by Benin's authorities. Some errors clearly suggest that the initiators of the draft texts have not necessarily understood the meaning and spirit of the texts of EU food law. For example, one might point out articles where references are wrongly made. This is the case for articles 50 and 51 of Order 075 of Benin which provides measures of crisis management to supplement the measures set by article 47, if this latter proves inadequate to ensure efficient management of food risks. While in the EU GFL, this reference relates to emergency measures for imported products, the correlation is established under Beninese law with regard to professional secrecy ${ }^{67}$. Those contradictions are likely to compromise the implementation of the laws.

Similarly, one could point out the non-coordinated efforts to comply at all costs with EU law. For example, certain concepts such as risk analysis that were never mentioned in Benin law and are largely unknown in Benin were suddenly introduced and defined in certain orders, while they did not have the slightest interest for the orders in question, and none of the articles refers to them. One could also mention the definition of drinking water under Beninese food law as "water at the point of compliance defined in Article 6 of Directive 98/83/EC and without prejudice to the requirements of Directives 80/778/EEC and 98/83/EC", while Benin has its own standard of drinking water since $2001^{68}$. To make it worse, there was not even given a slight hint concerning the defini-

67 Article 50 provides that a general plan be established to clarify the practical modalities for managing a crisis whose risks cannot be effectively prevented, eliminated or reduced to an acceptable level by the provisions of Article 47. Similarly, Article 51 refers to the same Article 47, and requires the Competent Authority to inform Beninese authorities whenever measures of Article 47 are not sufficient for an efficient management of risks involved. However, contrary to expectations, the Article 47 invoked in both cases does not provide any measure of food risk management. It states: "The protection of professional secrecy shall not prevent the dissemination to the competent authorities of information relevant to the functioning of market surveillance and enforcement in the field of food and feed. The authorities receiving information covered by professional secrecy shall ensure its protection in accordance with Article 46."

68 Decree No. 2001-094 of 20 February 2001 laying down quality standards for drinking water in Benin. tion of drinking water as provided by that EU directive.

\section{Effectiveness of the EU approach}

Despite the serious shortcomings revealed by the FVO inspection in Benin in 2002, and the subsequent recommendation to take protective measures against Benin, the EU did not officially take any action. Therefore Benin remained on the list of countries that were authorized to export to the EU. This implies that, with regard to EU law, Benin was still considered a potentially 'safe source' for fishery products. The next EU step constituted in 'lifting' the ban on shrimp exports in Benin by confirming its safe source status through Regulation 2076/2005/EC, allowing Benin to export to the EU through bilateral agreements. The legitimacy of this step can be questioned because it did not follow a new inspection in Benin as previously planned, to check the actual improvement that had occurred. Given the serious shortcomings still revealed in 2009, one could assume that the food safety law and system in Benin in 2005 would not be any different. The adoption by Benin of a new legislation was no guarantee of a better enforcement that would lead to safer products. In this regard, giving approval on the basis of written guarantees provided by Benin is again a return to the documentary assessment approval system with its inherent flaws.

In another step, the EU granted list I status to Benin after the FVO inspection of 2009, simply on the basis of the equivalence established between Benin and EU laws, even though the inspection also revealed significant shortcomings in the entire implementation system. This second approval not only confirmed Benin as a safe source for fishery products, but also 'promoted' it for its efforts to comply with EU law. This process does not take into consideration two essential aspects. First, the past records of weak enforcement plaguing Benin's history combined with the poor performance resulting from nearly a decade of reforms reasonably suggest that food safety is still and might continue to be an issue in Benin in the short-term. Secondly, Benin's government had not shown a real commitment in the upgrading process. All major reforms and needed expertise were subject to donors' assistance, while Benin neglected its share. This dependence on exter- 
nal aid to reach the food safety objectives set by a 'too high-quality' legislation is also an indication that the food safety level might stagnate or even regress in the near future. This is already evidenced by many unfinished works such as the platforms of transfer or the equipment of laboratories. The lack of properly functioning laboratories in Benin entails a lack of accreditation, which in turn implies that the EU cannot - or should not? - fully trust test results and certification from Benin.

From a legal perspective, demanding conformity requires harmonization of third countries legislation with the one of the EU. Since it is well acknowledged that EU law is more stringent than international standards, harmonization in this context will then imply a departure from what is required in WTO law. Indeed, both the SPS and the TBT Agreements encourage harmonization as a trade facilitation tools, to the extent that the required harmonization is based on international standards ${ }^{69}$. Equivalence enables regulatory diversity by encouraging countries to accept their differing regulations as equivalent, provided that the exporting country's measures can satisfy the level of protection set by the importing Member. Therefore the EU requirement for conformity or equivalence leaves much regulatory space for exporting countries to choose the best alternative for them in their search for gaining access to the EU market. This approach goes even a step further by establishing a one-way equivalence assessment which relieves the exporting Member from the burden of establishing itself the equivalence with EU law.

In this way, the choice of Benin to harmonize its law with EU law is a sovereign decision. However, upgrading regulations reactively always limits the regulatory autonomy of the Member concerned, particularly when there is a threat of an import ban from the importing country in the case of non-compliance. After Benin committed through the action plan, it established with the EU a sort of contract whose violation could lead to a EU protective measure. Therefore, it became urgent for Benin to actually undertake regulatory reforms that led to the copy-pasting of EU law. This obvious violation of the legitimate legislative process can be explained for a large part by the exclusive dependence on the EU market, which places on Benin an immediate pressure to seek ways to comply. But considering the limited national capacities and financial resources, this reactive approach combined with the threat of an imminent ban leave little room for coordinated self-conceived strategies that would reveal more appropriate to domestic needs. However, such a focus on national needs has a variety of challenges. First, it might be quite time-consuming and lead, at least temporarily, to the much-feared EU ban. Besides, this strategy was not attractive due to the extreme reliance on donors' assistance to undertake the necessary reforms. Lastly, referring to article 4.2 of the WTO SPS Agreement, Benin would bear the burden of objectively demonstrating that its law can reach the same level of protection as attained by EU law. Copy-pasting EU law appears to be the best way to circumvent this challenging requirement that calls for sufficient expertise.

In fact, this situation creates two domestic supplychains for shrimps. On the one hand, a supply-chain for the domestic market to which still applies the 'old non-compliant' system with all related shortcomings. On the other hand, there is a second supply-chain that follows the rule of the borrowed legislation and tries to comply with EU law. Whether this second supply-chain leads to safer shrimps is still questionable. In reality the same small-scale actors (fishermen, fishmongers) supply fresh shrimps to the domestic market and the processing plants for exports to the EU. According to a survey, the awareness of the fishing community of the compliance issue is still relatively low ${ }^{70}$. This fact alone can undermine the whole process because the quality of the finished product is closely linked to the quality of the raw material. Besides, after the first upgrading measures and the authorization to resume export that ensued in February 2005, Benin was mentioned four times in the RASFF. These notifications are evidence that despite the improvement in the regulatory framework, some more steps as regards implementation were still necessary to reach an actually improved quality of the shrimps. But most importantly, the FVO report in 2009 showed that the production and control system was still not reliable. Therefore, the CA in Benin cannot provide assurance that the inspection of the shrimps was performed in an equivalent way to that of the EU. Seen in this light, if the shrimp export sector was still functional, the EU's approval allows a

69 Article 3.1 of SPS Agreement, and 2.4 of the TBT Agreement.

70 Romain Houssa and Marijke Verpoorten, The Unintended Consequence of an Export Ban: Evidence from Benin's Shrimp Sector, CRED Working Paper 1304, (2013), at p21 
loophole in its own system that could result in potentially harmful products on its market. Therefore, the legitimacy of the EU approach in ensuring proper controls over the food safety system of third countries is undermined by the inconsistencies between the results reported and the actions taken by the Commission. This kind of process has been labelled whitecoat machinery to reassure insecure European regulators and consumers ${ }^{71}$. Genuine health concerns should not be compromised in front of evidence of the unreliability of a food safety system of a given third country. Thus, equivalence must not be granted on dubious grounds, because it might take away the very benefits of the establishment of equivalence such as the elimination of duplicative testing procedures.

\section{Conclusion}

The inconsistency between the provisions of the laws and their implementing decrees has been blamed as the main weakness of the food safety law in Benin ${ }^{72}$. Stakeholders often blamed this inconsistency as a reason for the weak implementation of the law. However, inconsistencies in regulation are probably not the only reason for failing food safety law. Despite the efforts made at both the legislative and institutional levels to improve the legislative and institutional framework, the lack of appropriate capacity in terms of inspections, monitoring and analysis, and

71 Stefano Ponte, supra note 10 . This white-coat machinery consists in "fixing the system of regulations and inspection and by performing the ritual of laboratory testing for all exports consignments". The phrasing had been specifically used to qualify a similar situation of alternative bans and lifts of bans that occurred in Uganda in the end of the nineties. More generally, the EU import bans had then affected the countries that export to the EU Nile Perch captured in lake Victoria. Various reasons motivated those bans such as cholera outbreak in the region, alleged poisoning of the lake from the use of pesticides as means of capture, deficiencies in the regulatory and control systems.

72 Mohamed Amaskane, Appui aux Systèmes d'Information sur les Mesures Sanitaires et Phytosanitaires au Benin, Rapport de Mission MTF/BEN/053/STF, at p16, 2010.

73 Not only in Benin, but also more generally see: Edward M. Wise, The transplant of legal patterns, The American Journal of Comparative Law, Vol 38 pp 1-38 (1990) at p3.

74 EU food law provides for a system of traceability that enables the recall of products for which doubts subsist as to their safety for consumption. In the same way, consignments that are found failing to meet the requirements must be seized or destroyed according to the seriousness of the risk. However this does not happen in practice. Problems are solved contractually among the parties, usually with a price discount. (See Stefano Ponte, supra note 10$)$. the fragmentation of stakeholders' responsibilities are still a major impediment to the proper implementation of the law in practice. To some extent paradoxically the chaotic situation both in formal regulation and in practice is partially the result of desperate efforts of Benin to comply with relevant provisions of EU law. First, the legislative process that started in 2003 aimed to somehow reproduce the provisions of EU Directive 91/493. In a second step, the focus was on the virtually blind transposition of the current EU food legislation into Benin law. It should be noted that the reforms undertaken were intended exclusively for the export-oriented industry so as to secure their market share. As a result, even the implementation efforts are only oriented towards that sector. However, the shrimp export sector in Benin has largely disappeared. Therefore, it appears that there is no internal demand that could induce additional efforts of implementation. The lethargy is likely to persist, as society seems to have a remarkably high tolerance for unsuitable law ${ }^{73}$.

The fact remains that in spite of the persistent inconsistencies with regard to the institutional framework and the conditions of production, the EU has given its approval to Benin on the basis of the "compliant" legislation and the guarantees to further pursue the capacity building process. This shows some more general weaknesses concerning the control and approval procedures in force within the EU. An excessive focus on the equivalence of the legislation seems to pay little regard to actual compliance with respect to implementation and enforcement. This formal control seems to be just a way of showing the willingness to give EU consumers the feelings that the situation is under control, while some potentially harmful products may still find their way to the EU market ${ }^{74}$. This can be evidenced by the numerous notifications through the RASFF. Not only can this policy be inefficient in protecting EU consumers, it may also be problematic from a development perspective.

In spite of EU assistance via its trade capacity building programs, the shrimp export industry in Benin has simply been wiped out. Moreover Benin is not able to effectively implement its "compliant" food law, because of recurrent financial and technical problems. In this respect, the demands of the EU were mostly a triggering factor to the collapse of the shrimp export industry in Benin. The pressure resulting from EU requirements would have been less dis- 
astrous without the presence of other key factors. First, exclusive reliance on donors' assistance to improve the institutional environment is a major impediment in the upgrading process. Secondly, the shrimp export industry was too small and too depending on the EU market to attract the adequate adherence from the government and the local financial institutions.
Could one then conclude that Africa and in this particular case Benin and the EU remain worlds apart? As this case showed, the EU subtly asserts its hegemony while the African state seems (given economic pressure) to be willing to cooperate. They seem to see eye to eye as to the results of a proper food safety law, but their challenges and local contingencies are fundamentally in conflict. 